\title{
Lip and Oral Cavity Cancer pNX TNM Finding v6 and $v 7$
}

National Cancer Institute

\section{Source}

National Cancer Institute. Lip and Oral Cavity Cancer pNX TNM Finding v6 and v7. NCI

Thesaurus. Code C64419.

Lip and oral cavity cancer in which the regional lymph nodes cannot be assessed. (from AJCC 6th and 7th Eds.) 